\title{
Transport of Dungeness crab Cancer magister megalopae into Glacier Bay, Alaska
}

\author{
Heidi Herter*, Ginny L. Eckert \\ Juneau Center School of Fisheries and Ocean Sciences, University of Alaska Fairbanks, Juneau, Alaska 99801, USA
}

\begin{abstract}
Larval behaviors and physical forcing mechanisms contributing to the transport of Dungeness crab Cancer magister megalopae into inlets have been determined for many areas along the coastlines of Washington, Oregon and California, but have never been examined in Alaska. In 2004 and 2005, we observed transport of C. magister megalopae into Glacier Bay through patterns of depth, spatial and temporal variation among 3 sites located at 8, 12 and $18 \mathrm{~km}$ from the Bay's mouth using light traps. At each site, 96.5 to $99.4 \%$ of megalopae were captured by traps positioned within $1 \mathrm{~m}$ of the surface, and few were captured in traps within $1 \mathrm{~m}$ of the bottom (10 m depth). Megalopae abundance decreased with increasing distance from the mouth of Glacier Bay, with the highest abundance captured in Bartlett Cove, followed by the South Beardslee Islands, and very few megalopae were captured in the North Beardslee Islands. Transport processes were correlated with proxies for lunar cycle, tidal amplitude, maximum sustained wind speed and interactions among these effects. Few megalopae were captured at any site during $3 / 4$ and full moon periods. High megalopae abundances in Bartlett Cove were associated with new to $1 / 2$ moons and tidal amplitudes of 300 to $499 \mathrm{~cm}$. Pulses of megalopae in the South Beardslee Islands occurred during new and $1 / 4$ moons with tides of 500 to $599 \mathrm{~cm}$ and moderate winds. Variation in megalopae supply to sites in lower Glacier Bay may be explained by differences in hydrodynamics, even among sites separated by less than $10 \mathrm{~km}$.
\end{abstract}

KEY WORDS: Cancer magister · Dungeness crab · Larval transport · Marine reserve $\cdot$ Recruitment Southeast Alaska $\cdot$ Spatial variability $\cdot$ Temporal variability

Resale or republication not permitted without written consent of the publisher

\section{INTRODUCTION}

Settlement of Dungeness crab Cancer magister megalopae in inlets along the coastlines of Washington, Oregon and California has been linked to a wide variety of larval behaviors and oceanographic transport processes, but such processes have never been examined in Alaska. Transport processes are typically examined by comparing megalopae abundance over depth, space or time. The behavior of adult and larval Dungeness crabs along the coast of the contiguous USA facilitates large-scale larval migration away from and then back to estuarine and nearshore areas (Lough 1976, Reilly 1983). Larvae off the Washington, Oregon and California coasts are found at progressively farther distances from shore with each larval stage (Lough 1976, Reilly 1983, Jamieson \& Phillips
1988, McConaugha 1988, Jamieson et al. 1989). Megalopae in early intermolt have been observed beyond the edge of the continental shelf, up to $170 \mathrm{~km}$ off the coasts of Washington and Vancouver Island (Jamieson et al. 1989) and $185 \mathrm{~km}$ off the coast of California (Reilly 1983). Megalopae are then transported back into nearshore areas (Jamieson \& Phillips 1993, Eggleston \& Armstrong 1995, Johnson \& Shanks 2002, Miller \& Shanks 2004) where larval settlement occurs (Carrasco et al. 1985, Jamieson \& Phillips 1988, McConnaughey et al. 1992).

Behaviors maintaining Cancer magister megalopae in surface waters facilitate transport by physical forcing mechanisms (McConaugha 1988), whereas behaviors that maintain megalopae near the bottom facilitate retention. Megalopae supply to specific nearshore areas along the Pacific USA coast has been linked to 
lunar phase (Eggleston \& Armstrong 1995), which is likely to affect behaviors controlling depth distribution. Megalopae supply is highly pulsed, and temporal variation in megalopae supply is also often related to physical forcing mechanisms, such as tide (Johnson \& Shanks 2002, Miller \& Shanks 2004) and wind events (McConnaughey et al. 1992, Jamieson \& Phillips 1993, Eggleston \& Armstrong 1995, Miller \& Shanks 2004).

As megalopae are transported into estuarine areas, spatial variation is thought to result from transport processes and local hydrodynamics (Botsford et al. 1989, 1998, Shanks \& Roegner 2007). For example, spatial variations in Cancer magister megalopae recruitment between areas separated by less than $10 \mathrm{~km}$ in Grays Harbor, Washington and Willapa Bay, Oregon, have been attributed to wind effects (Eggleston \& Armstrong 1995, Roegner et al. 2003). Such effects are highly variable among locations and difficult to extrapolate out of the immediate area. Larger scale processes may be responsible for more regular spatial and interannual variations along an entire coastline. Shanks \& Roegner (2007) recently determined that an earlier spring transition off the Pacific USA coast is associated with higher supply of Dungeness crab megalopae to nearshore areas off the Oregon and California coasts and that interannual variation in megalopae supply is predictive of the commercial harvest in those areas after a 4 yr growth period.

The Dungeness crab fishery is an important part of Alaska's economy with an average annual value of US \$6740000 from 1998 to 2002 (Woodby et al. 2005). The average annual harvest during this time period was 2050 t, 1810 t of which came from southeast Alaska (Woodby et al. 2005). However, patterns of larval transport have been little studied in southeast Alaska, despite the economic importance of this fishery. The effects of lunar cycle, tides and wind on megalopae transport into bays along the coast of the contiguous USA are difficult to apply to Glacier Bay. Coastal Alaska is a highly complicated matrix of islands, bays, fjords and inlets which cannot be compared with the relatively straight coastlines of Washington, Oregon and California. The inside waters of southeast Alaska are most comparable to Puget Sound and the Georgia-Rosario Strait complex separating Washington and British Columbia, which is a known retention zone for Dungeness crab larvae (Jamieson \& Armstrong 1991). The influence of this unique coastline geography and oceanic regime on megalopae transport and settlement is unknown.

Larger scale processes determining interannual variation in Dungeness crab megalopae to the contiguous USA have little relevance in Alaska because of the very different current system along the outer coast of Alaska. Off Vancouver Island, the eastward-flowing Subarctic Current impinges on North America and bifurcates into the southward-flowing California Current and the northward-flowing Alaska Current (Sverdrup et al. 1942). The California Current regime can be characterized by upwelling and relaxation events (Huyer 1983); whereas, the Alaska Current regime is downwelling year-round (Royer 1998, Weingartner et al. 2005). Larvae subjected to downwelling along the outer coast may be thereby concentrated in bottom waters at the edge of the narrow continental shelf in the Gulf of Alaska (GOA); however, the potential effects of oceanographic processes on larval transport are poorly understood in this region.

Glacier Bay is a major focal point in Alaska for oceanography (Hooge \& Hooge 2002, Etherington et al. 2004, 2007, Hill 2007) and Dungeness crab research (i.e. O'Clair et al. 1995, 1996, Taggart et al. 2003, 2004a,b, Fisher 2005, 2006). The commercial Dungeness crab fishery in Glacier Bay was closed by US Congress in 1998 (Department of the Interior 1998), creating the largest $\left(1255 \mathrm{~km}^{2}\right)$ functional marine reserve for Dungeness crabs throughout their range. Recent studies suggest that Cancer magister larvae are exported from Glacier Bay during early zoeal stages as has been shown in estuaries along the USA Pacific coast (Fisher 2005, G. L. Eckert unpubl. data). Fisher (2005) found the abundance of C. magister zoeae in Sitakaday Narrows, Glacier Bay, to decrease throughout summer months. Plankton tows in April through June 2002 captured stages I and II zoeae in average densities of 10 larvae $100 \mathrm{~m}^{-3}$, whereas sampling in July and August captured few larvae in later zoeal stages, suggesting that early-staged C. magister zoeae may be exported from Glacier Bay (Fisher 2005). In comparison, high mean densities (1100 to 5200 larvae $100 \mathrm{~m}^{-3}$ ) of the congener Cancer oregonensis were captured in plankton tows in all months and included zoeae up to stage IV, suggesting that this species is retained in Glacier Bay during summer months. Summer sampling of crab larvae throughout all of Glacier Bay yielded similar results, with very few C. magister zoeae but high numbers of $C$. oregonensis zoeae captured (G. L. Eckert unpubl. data). Despite the absence of late-stage zoeae in the lower Bay during summer months, high numbers of megalopae have been captured in Bartlett Cove (BC), Glacier Bay, using light traps with fluorescent bulbs (authors' unpubl. data). Settlement in this area occurs during September and October, which is much later than the settlement season for Dungeness crabs along the coast from California to British Columbia (authors' unpubl. data). Megalopae abundance in BC varies by an order of magnitude interannually with maximum daily counts up to 12000 megalopae trap ${ }^{-1}$ in 2000 (authors' unpubl. data) and is highly pulsed, suggesting transport into Glacier Bay. 
Alaska is the heart of the distribution for this species and yet very little is known about the larval life history of Dungeness crabs in this region. The present study is the first to document patterns of depth, spatial and temporal variations that indicate transport of Dungeness crab megalopae into an Alaskan estuary. Transport mechanisms were related to lunar cycle, tides and wind with spatial variation in megalopae supply among sites which may result from local hydrodynamics.

\section{MATERIALS AND METHODS}

Study area. Glacier Bay, Alaska, is located $50 \mathrm{~km}$ from the GOA and connected to the GOA through Icy Strait and Cross Sound $\left(58.40^{\circ} \mathrm{N}, 136.02^{\circ} \mathrm{W}\right.$; Fig. 1). Cross Sound narrowly opens to the GOA at a canyon that slopes downward and outward through the narrow coastal shelf ( $35 \mathrm{~km}$ wide) to the shelf break. Glacier Bay is a Y-shaped and recently deglaciated $(<300 \mathrm{yr}$ ago) fjord stretching ca. $100 \mathrm{~km}$ from north to south. Glacier Bay is a highly variable and dynamic area experiencing large amounts of freshwater runoff, high sedimentation and large semidiurnal tidal variations. It is surrounded by mountainous terrain with many freshwater sources including 10 tidewater glaciers in the upper Bay. The bathymetry of Glacier Bay is highly varied due to recent glacial recession. The main feature of the lower Bay is Sitakaday Narrows, a narrow ( 4 to $8 \mathrm{~km}$ ) constriction in the main body of the Bay leading into the Beardslee Island complex $\left(58.48^{\circ} \mathrm{N}\right.$, $136.02^{\circ} \mathrm{W}$ ). Sitakaday Narrows is shallow (50 m deep) and the water column is mixed 4 times daily during maximum ebb and flood tides (Hooge \& Hooge 2002). The central and upper portions of Glacier Bay are characterized by stratified basins up to $400 \mathrm{~m}$ deep. Average tidal amplitudes in BC are $3.7 \mathrm{~m}$ and can be as large as $7.3 \mathrm{~m}$ (Hooge \& Hooge 2002).

Light traps. Light traps are commonly used to study transport processes for brachyuran crabs (Reyns \& Sponaugle 1999, Johnson \& Shanks 2002, Roegner et al. 2003, Miller \& Shanks 2004, Shanks 2006). Light traps are self-sufficient, inexpensive and more efficient at catching fast-swimming megalopae than plankton nets (Porter et al. 2008). Light traps also sample over an extended time frame and mitigate patchiness of megalopae in surface waters (Natunewicz \& Epifanio 2001, Jones \& Epifanio 2005). The light traps used in the present study were modified from the Roegner et al. (2003) design. Translucent 201 rectangular containers made of plastic were fitted on each side with transparent funnels which tapered from 100 to $10 \mathrm{~mm}$ in diameter. The bottom of the trap was capped with a removable PVC tube with $250 \mu \mathrm{m}$ mesh at the cod end.

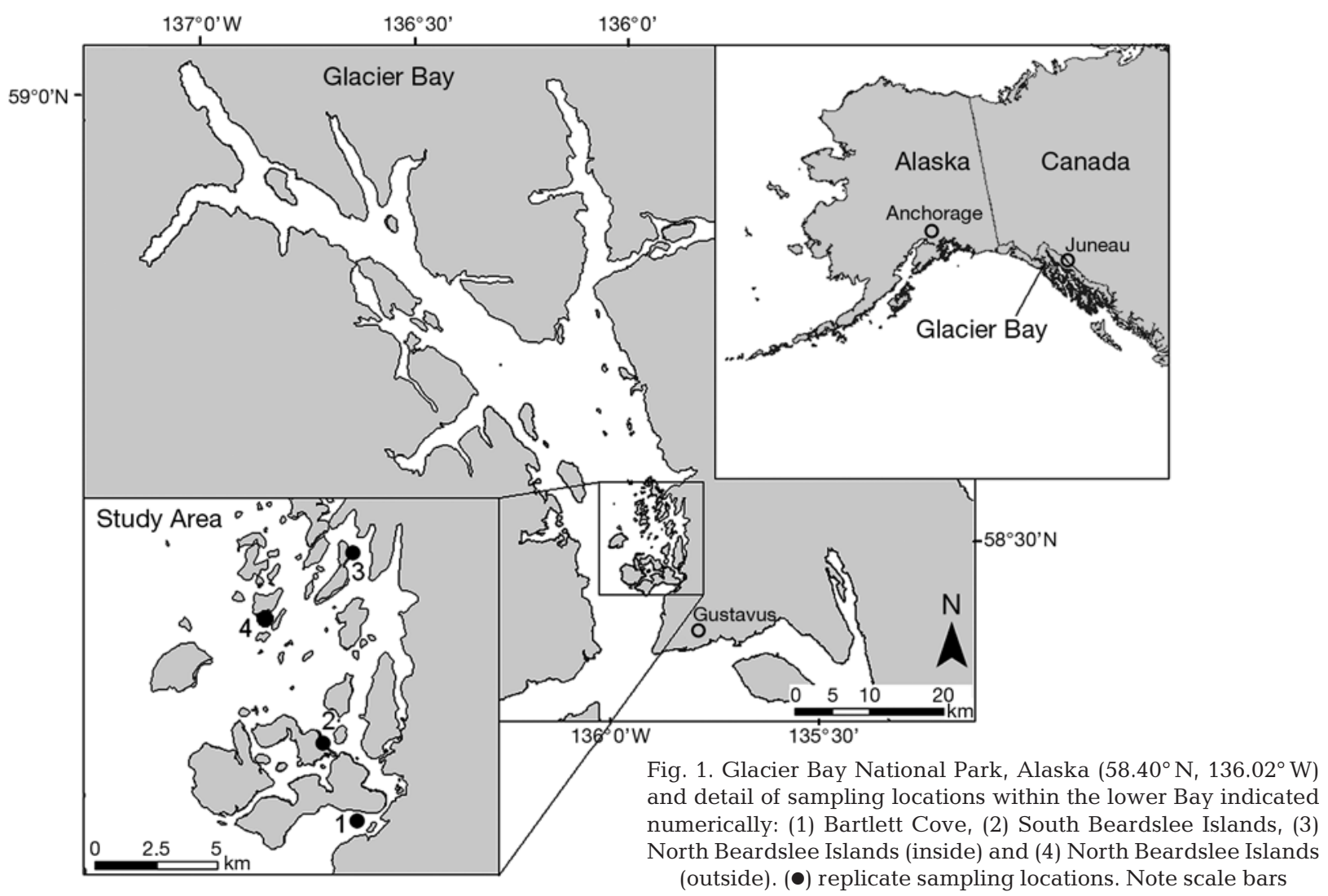


As traps were lifted from the ocean, the water inside was expelled through the mesh, concentrating larvae in the cod end for collection. Weights on the bottom and foam floats on top ensured that the light trap remained upright in the water column. Constant illumination was provided by 2 Princeton Tec Attitude ${ }^{\circledR}$ dive lights (total 6 LED lights trap ${ }^{-1}$ ) affixed inside each trap. Batteries in the lights were changed every $2 \mathrm{~d}$ to maintain consistent light levels.

Sampling regime. Samples were collected in sites within the lower portion of Glacier Bay, including BC, the South Beardslee Islands (SB) and the North Beardslee Islands (NB). Sampling sites were positioned along a gradient of increasing distance $(8,12$ and $18 \mathrm{~km}$, respectively) from the mouth of Glacier Bay and were separated by distances ranging from 4 to $12 \mathrm{~km}$. Two light traps were positioned on each of 3 replicate mooring lines at each site with 1 light trap positioned within $1 \mathrm{~m}$ of the surface and the other within $1 \mathrm{~m}$ of the bottom. Locations for the 3 mooring lines at each site were selected randomly from adult crab pot survey sites at $10 \mathrm{~m}$ depth mean lower low water (MLLW) (Taggart et al. 2004a,b). Surface traps were suspended from buoys, and the bottom traps were fixed by an anchor so that traps remained in their respective positions throughout tidal cycles.

A pilot study was conducted in 2004 in which 3 primary sites (Fig. 1) were sampled at the surface on $12 \mathrm{~d}$ between 19 September and 19 October (see Herter 2007 for dates). BC, which is more easily accessed, was sampled on a daily basis over this time period. Bottom traps were sampled on a subset of these dates because so few megalopae were collected in these traps that a subset was considered to be sufficient for depth comparisons. Some replicate samples were lost this first year due to gear failure and bad weather, especially in SB.

In 2005 a complete time series of daily surface samples was collected in $\mathrm{BC}, \mathrm{SB}, \mathrm{NB}$ and the outside NB from 17 October to 31 October, with bottom traps sampled once again on a subset of these days. Sampling prior to 16 September was not possible in the Beardslee Islands because the area is closed by the National Park Service to motorized vessel traffic from 1 May to 15 September.

It was thought that the island archipelago might restrict water flow, thereby restricting megalopae supply, to the inside site. The outside site was added to sample spatial variation over a wider area in NB and to limit water flow as a confounding factor. This new site was not sampled during the adult pot survey (Taggart et al. 2004a,b) from which light trap locations were selected for the other sites. Replicate mooring lines at the outside NB site were positioned with similar spacing to the other sites at ca. $120 \mathrm{~m}$ intervals along the $10 \mathrm{~m}$ MLLW contour line.
Sample identification. Fish and other macroscopic, non-decapod organisms captured in light traps were identified, recorded and released at the time of sampling. The remainder of the sample was preserved in $80 \%$ ethanol for lab processing in which brachyuran larvae were identified according to Lough (1974) and Shanks (2001) and enumerated. Larvae of commercially valuable crabs Cancer magister and Chionoecetes bairdi were identified to species and larval stage. Larvae of other crabs were identified to family (Cancridae, Grapsidae, Xanthidae, Pinnotheridae, Paguridae and Majidae).

Physical data. A lunar calendar was downloaded from the US Naval Observatory Astronomical Applications Department (2005). Tide predictions were generated online by the XTide program (University of South Carolina 2006) with BC tides used as an approximation for all sites. Although predictions based on BC tides may be somewhat different from actual tides in the Beardslee Islands, BC is the only sampling site where tidal information is collected in the lower Bay. Tidal amplitudes for each day were estimated as the difference between the highest high and lowest low tides for every $24 \mathrm{~h}$ period from noon of the previous day to noon of the sampling day. Wind data were collected ca. 10 miles $(16 \mathrm{~km})$ east of the sampling sites, at Stn $703670\left(58.41^{\circ} \mathrm{N}, 135.70^{\circ} \mathrm{W}\right)$ in Gustavus, Alaska, by the National Climatic Data Center (US Department of Commerce 2006). Maximum sustained daily wind speed was defined as the highest recorded daily value from these hourly data. Since wind data were not collected in the immediate sampling area, they may or may not accurately reflect winds at our study sites. Therefore, wind direction was not considered in this analysis.

Statistical analysis. Data were analyzed using SAS statistical software (version 9.1). The number of megalopae in each light trap was transformed by $\log _{10}$ (abundance +0.1 ) to reduce and normalize variance prior to all analyses. Depth variation in megalopae abundance was analyzed with a 2-way fixed factor general linear model (GLM) and Tukey-Kramer post hoc tests on least squared means for effects of location (BC, SB and NB) and depth (surface and bottom) for the subset of days when bottom traps were sampled. Spatial variation in megalopae abundance was assessed for surface traps with a 2-way fixed-factor GLM and Tukey-Kramer post hoc tests for effects of year (2004 and 2005) and location (BC, SB and NB). Years were pooled in this analysis of depth effects, and only days for which at least 2 sites were sampled were used in this analysis. Because megalopae recruitment is seasonal and periodic, autocorrelation occurs in this type of data set (Bence 1995). Spatial variation in megalopae abundance in 2005 was compared across time 
using a repeated measures GLM. Repeated measures analysis accounts for non-independence of samples collected from the same light traps over the study period. Mean surface abundances of megalopae in the inside and outside NB in 2005 were compared with a 1-tailed $t$-test for samples with equal variances to assess spatial variation between those sites.

Temporal variation in megalopae abundance in 2004 and 2005 was analyzed for a relationship with physical parameters with a 3-way fixed factor GLM and TukeyKramer post hoc tests for effects of lunar period, tidal amplitude and maximum sustained wind speed. Qualitative lunar phase groups were created based on the fraction of the moon illuminated as follows: new moon $=0$ to $10 \% ; 1 / 4$ moon $=11$ to $34 \% ; 1 / 2$ moon $=35$ to $60 \% ; 3 / 4$ moon $=61$ to $89 \%$; and full moon $=90$ to $100 \%$. Tidal amplitude was separated into $100 \mathrm{~cm}$ intervals (200 to 299, 300 to 399,400 to 499,500 to 599 and 600 to 699 ). Maximum daily wind speed values were grouped into low, moderate and high wind categories as follows: low, $<4 \mathrm{~m} \mathrm{~s}^{-1}$; moderate, 4 to $7 \mathrm{~m} \mathrm{~s}^{-1}$; and high, $>7 \mathrm{~m} \mathrm{~s}^{-1}$. These brackets were created with the intention to split both the number of available data points and the range in wind values as evenly as possible.

Time series of megalopae abundance at each site in 2005 were analyzed for autocorrelation and crosscorrelated with proxies for behavioral and physical effects on transport, including lunar cycle, tidal amplitude and maximum sustained wind speed. Periodicity in megalopae abundance could be indicative of physical processes affecting transport (i.e. autocorrelation with $14 \mathrm{~d}$ periodicity would be indicative of a tidal influence). To avoid a seasonal effect in cross-correlations, we truncated the data set at the end of the last pulse on 29 October 2005. By examining only the relatively brief window when megalopae were most abundant (43 d), we avoid the effects of low numbers of available megalopae early and late in the settlement season. Johnson \& Shanks (2002) and Miller \& Shanks (2004) removed the seasonal trend in megalopae abundance from their longer data sets by subtracting a moving average to obtain residuals; however, this transformation truncates time series by the length of the moving average. We presumed that a seasonal component would not affect correlations with physical processes during the peak period of larval recruitment and preserved the length of our dataset by subtracting the mean, rather than a moving average.

Cross-correlations compared these residuals of megalopae abundance with residuals from physical parameters at lags of $\pm 5 \mathrm{~d}$, since cross-correlations are only considered statistically significant for lags $<10 \%$ of the length of the time series (Emery \& Thomson 1997). Residuals for tidal amplitude and maximum sustained wind speed were similarly calculated by subtracting each mean seasonal value from daily values. Lunar cycle was converted into a time series by defining the new moon residual as 0.5 and the full moon residual as -0.5 with other values falling in between. Crosscorrelation analyses must always be treated with caution as nonsensical correlations may occur (i.e. Love \& Westphal 1981).

\section{RESULTS}

\section{Depth variation}

High abundances of megalopae were captured at night in surface traps while very few were captured in bottom traps. Megalopae abundance was significantly higher in surface than in bottom traps in BC and SB, but not in NB where megalopae abundance was very low (Fig. 2, Table 1). Surface traps captured $98.7 \%$ of the total megalopae collected in BC, $92.4 \%$ of the total megalopae collected in SB and $99.1 \%$ of megalopae in NB. The depth*location interaction effect was significant because surface samples from NB were not significantly different from bottom samples at BC ( $p=0.7928)$ or SB $(p=0.6153)$.

\section{Spatial variation}

Megalopae abundance decreased with increasing distance from the mouth of Glacier Bay for the sites

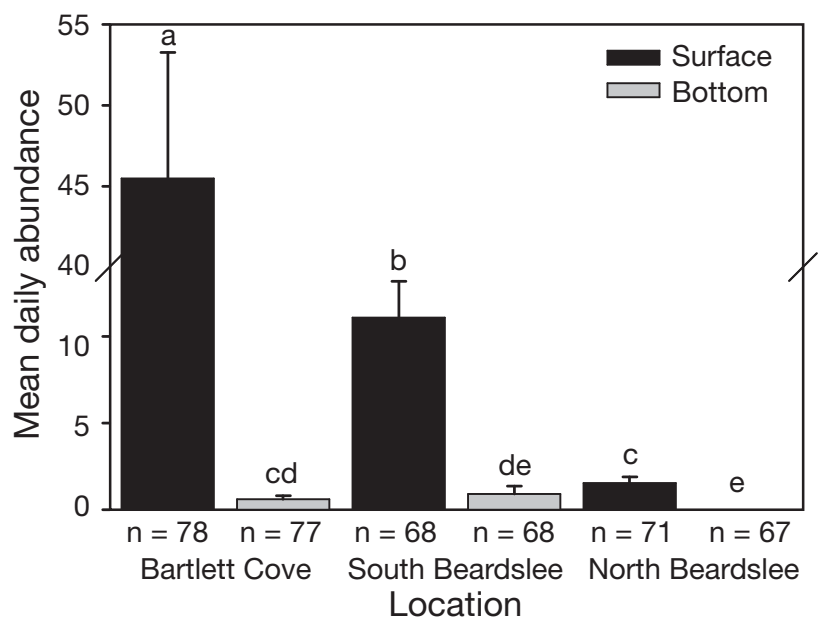

Fig. 2. Cancer magister. Depth variation in mean (+1 SE) daily megalopae abundance per light trap for samples collected within $1 \mathrm{~m}$ of the surface and at the bottom at $10 \mathrm{~m}$ depth. Bottom samples were taken on a subset of simultaneous days for all sites in 2004 and 2005. Letters indicate significant differences among sites and depths at $p=0.05$ 
Table 1. Summary of 2-way GLM with effects location (Bartlett Cove, South Beardslee Islands or North Beardslee Islands) and depth (surface or bottom) upon log-transformed daily Cancer magister megalopae abundance

\begin{tabular}{|lcccc|}
\hline Source of variation & $\mathrm{df}$ & $\mathrm{MS}$ & $F$ & $\mathrm{p}$ \\
\hline Location (fixed factor) & 2 & 32.50 & 71.76 & $<0.0001$ \\
Depth (fixed factor) & 1 & 158.55 & 350.02 & $<0.0001$ \\
Location ${ }^{\text {Depth }}$ & 2 & 12.30 & 27.16 & $<0.0001$ \\
Error & 423 & 0.45 & & \\
\hline
\end{tabular}

sampled. The highest megalopae abundance was in $\mathrm{BC}$, followed by $\mathrm{SB}$, with very few megalopae captured in NB. Patterns of spatial variation in mean daily megalopae abundance were similar in 2004 and 2005, suggesting that distribution among these sites may be similar from year to year. Differences in megalopae abundance were significant among all sites in 2005 (Fig. 3, Table 2). In 2004, megalopae abundance in NB was significantly lower than in the other 2 sites, but abundances in $\mathrm{BC}$ and $\mathrm{SB}$ were not significantly different from each other. Repeated measures analysis for the 2005 sampling season resulted in significant variation in megalopae abundances among $\mathrm{BC}, \mathrm{SB}$ and $\mathrm{NB}(\mathrm{df}=2,134, F=47.67$, $\mathrm{MS}=63.28, \mathrm{p}=0.0002$ )

Few megalopae were caught at the inside or outside NB sites, and megalopae abundances were not significantly different between those 2 sites (NB inside/outside: 1 -tailed $t$-test: $\mathrm{df}=1,178, \mathrm{p}=0.298 ;$ Fig. 4). Henceforth, these 2 locations will be referred to collectively as NB.

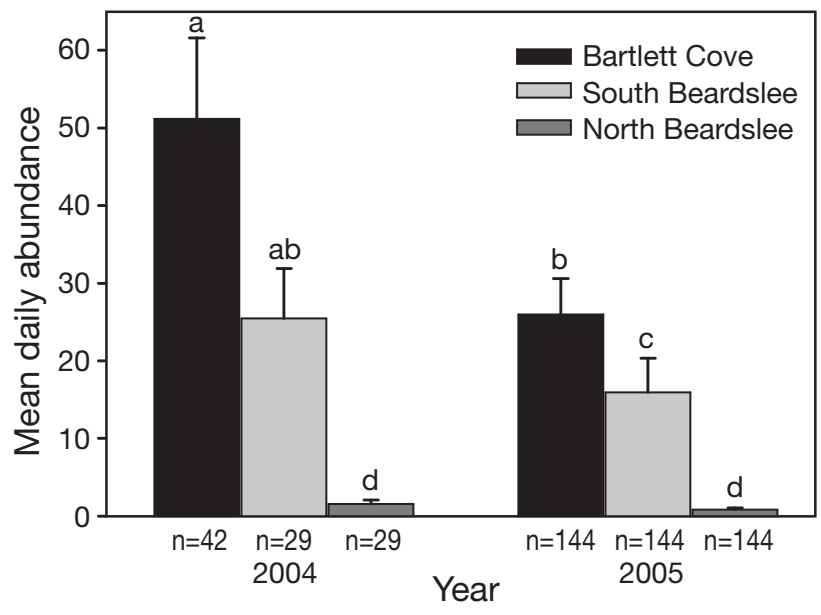

Fig. 3. Cancer magister. Spatial variation in mean $( \pm 1 \mathrm{SE})$ daily megalopae abundance per light trap in Bartlett Cove, the South Beardslee Islands and the inside North Beardslee Islands. Samples were collected within $1 \mathrm{~m}$ of the surface in 2004 and 2005. Letters indicate significant differences at $p=0.05$
Table 2. Summary of 2-way GLM with effects year (2004 or 2005) and location (Bartlett Cove, South Beardslee Islands or North Beardslee Islands) upon log-transformed daily Cancer magister megalopae abundance at the surface

\begin{tabular}{|lcccc|}
\hline Source of variation & df & MS & $F$ & $p$ \\
\hline Year (fixed factor) & 1 & 27.09 & 36.45 & $<0.0001$ \\
Location (fixed factor) & 2 & 60.93 & 81.99 & $<0.0001$ \\
Year* Location & 2 & 1.08 & 1.46 & 0.2336 \\
Error & 526 & 0.74 & & \\
\hline
\end{tabular}

\section{Temporal variation}

Megalopae abundances at all sites were characterized by large pulses with over half of the megalopae at each site collected over only 2 nights, the dates of which varied by location (Fig. 5; surface n 2005: BC 144, SB 144 and NB 144). Large pulses of megalopae occurred at $\mathrm{BC}$ on 3 October (mean $\pm \mathrm{SE}$ : $237.7 \pm 80.4$ ) and 10 October (mean \pm SE: $249.7 \pm$ 52.1). The 2 largest pulses in SB occurred on 5 October (mean \pm SE: $293.0 \pm 106.0$ ) and 21 October (mean \pm SE: $112.0 \pm 60.5)$. The highest megalopae abundance in NB occurred on 26 September (mean \pm SE: $10.7 \pm 1.7$ megalopae) and 5 October (mean \pm SE: $10.7 \pm 5.9$ megalopae). These pulses represented $55.7 \%$ of the total number of megalopae collected in $\mathrm{BC}, 52.9 \%$ of the total collected in SB and $52.9 \%$ of the total collected in NB.

Relationships between megalopae abundance and physical factors, or interactions between factors, differed by location (Fig. 6, Table 3). Significant physical

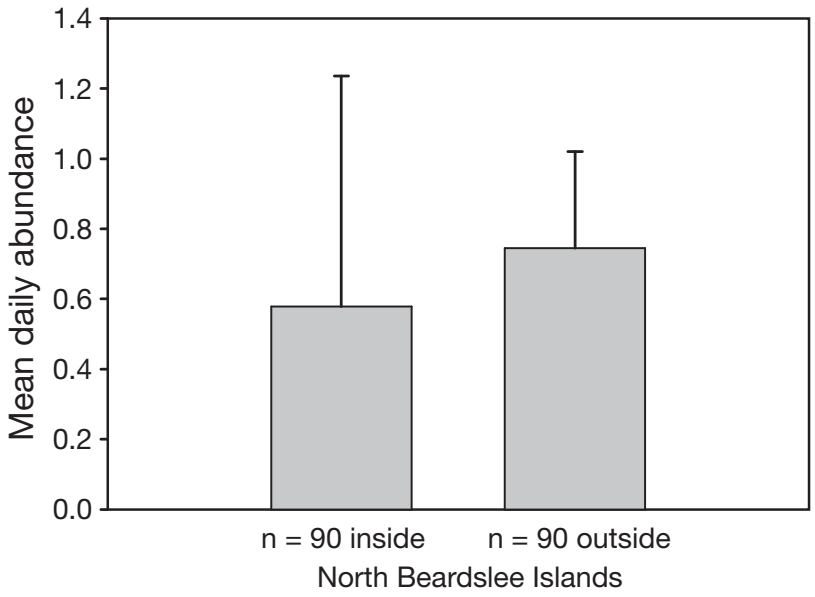

Fig. 4. Cancer magister. Spatial variation in mean $( \pm 1 \mathrm{SE})$ daily megalopae abundance per light trap inside and outside of the North Beardslee Islands. Samples were collected at the surface from 5 October to 3 November 2005. No significant difference between sites 


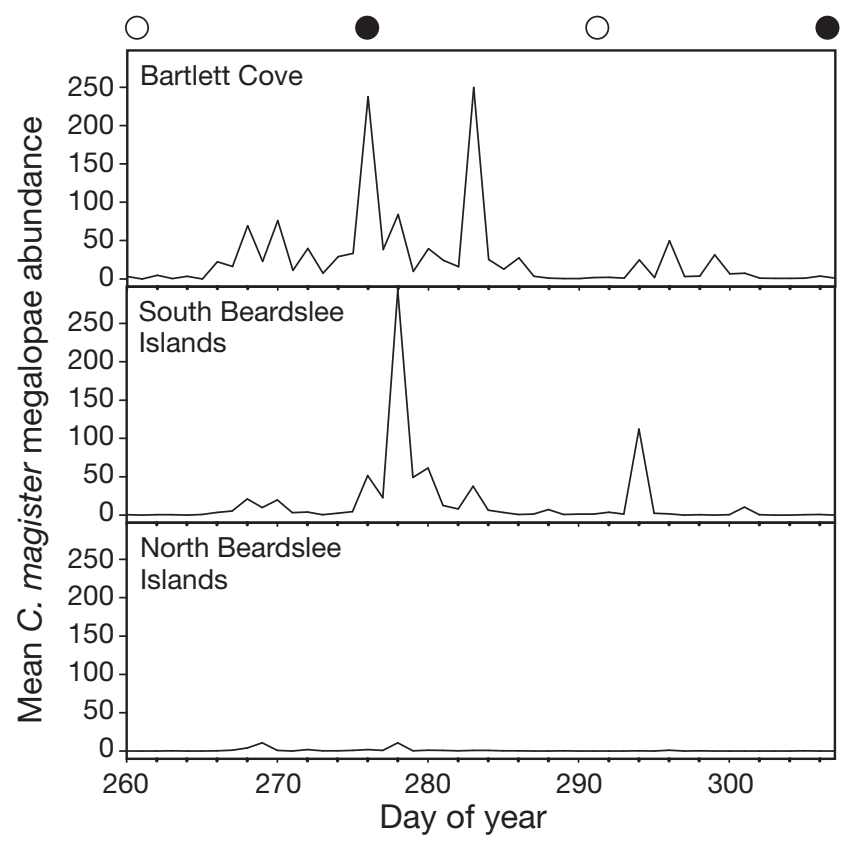

Fig. 5. Cancer magister. Time series of mean daily megalopae abundance in Bartlett Cove, the South Beardslee Islands and inside of the North Beardslee Islands from 17 September to 3 November 2005. The lunar calendar is represented by dark (new moon) and open (full moon) circles

influences on megalopae abundance in BC were lunar period, tidal amplitude, and the interaction between lunar period and tides (Table 3; $\mathrm{df}=27, \mathrm{MS}=3.35, F=$ 7.47, p < 0.0001). Low megalopae abundances were associated with $3 / 4$ to full moons (n lunar phase: new $=$ $45,1 / 4=39,1 / 2=24,3 / 4=27$ and full = 36) and high tidal amplitudes from 500 to $699 \mathrm{~cm}$ (n tidal amplitude in cm: $200=21,300=33,400=45,500=42,600=30$ ； p lunar*tides: $<0.05$ in 25 of 39 possible scenarios). The highest megalopae abundances occurred on new to $1 / 2$ moons (p: 0.0188 to <0.0001; Fig. 6), and on tides with amplitudes 300 to $499 \mathrm{~cm}$ (p: 0.0094 to <0.0001; Fig. 6). Significant physical influences on megalopae abundance in SB included lunar period, tidal amplitude, the interaction between lunar period and tides and the interaction between lunar period and wind (Table 3; df $=27, \mathrm{MS}=3.07, F=6.43, \mathrm{p}<0.0001)$. Megalopae supply to SB was very high during new to $1 / 4$ moons (n lunar phase: new $=41,1 / 4=29,1 / 2=24,3 / 4=27$, full $=$ 35; p lunar phase: 0.0355 to $<0.0001$; Fig. 6 ) and during high tides of 500 to $599 \mathrm{~cm}$ (n tidal amplitude in $\mathrm{cm}$ : $200=21,300=28,400=38,500=40,600=29 ; \mathrm{p}$ tidal amplitude: 0.0034 to 0.0004 ; Fig. 6 ); with an interaction between these effects ( $p$ lunar*tide: $<0.05$ in 6 of 13 possible scenarios). The highest megalopae abundances also occurred on new moons with moderate daily wind maxima of 4 to $7 \mathrm{~m} \mathrm{~s}^{-1}$ (n wind in $\mathrm{m} \mathrm{s}^{-1}:<4=$ 43,4 to $7=43,>7=70$; p lunar* wind: $<0.05$ in 7 of 14 possible scenarios). In NB, megalopae supply was not affected by any particular factor although the overall model was significant (Table 3 ; df $=25, \mathrm{MS}=0.66, F=$ $1.66, p=0.0367$ ). Data were reanalyzed with a 1 -way GLM for the effect of lunar period only (n lunar phase: new $=36,1 / 4=35,1 / 2=24,3 / 4=27$ and full = 33), and this model proved a better fit for the data with significantly lower megalopae abundances during $3 / 4$ and full moon periods $(\mathrm{df}=4, \mathrm{MS}=2.12, F=5.39$, lunar phase $\mathrm{p}$ : 0.0493 to 0.0014 ; Fig. 6).

\section{Cross-correlation analysis}

Time series of megalopae lacked clear periodicity and were autocorrelated within 1 to $3 \mathrm{~d}$ lags at $\mathrm{BC}, 1$ to $3 \mathrm{~d}$ lags at $\mathrm{SB}$, and 1 to $2 \mathrm{~d}$ lags at NB ( $\mathrm{n}=43$; Fig. 7 ). High numbers of megalopae in $\mathrm{BC}$ were associated with lunar phases up to $3 \mathrm{~d}$ before and $4 \mathrm{~d}$ after the new moon ( $\mathrm{n}=43, \mathrm{p}=0.006$ to 0.04 ; Fig. 8). Megalopae abundance was inversely related to tidal amplitude at $-2 \mathrm{~d}$ lags after and 0 to $+1 \mathrm{~d}$ before tides $(\mathrm{p}=0.0003$ to 0.005). Megalopae abundance in BC was not corre-

Table 3. Summary of 3-way GLM with effects lunar phase (new, $1 / 4,1 / 2,3 / 4$ and full), tidal amplitude (200 to 299,300 to 399,400 to 499,500 to 599 and 600 to $699 \mathrm{~cm}$ ) and maximum sustained wind speed $\left(<4,4-7\right.$ and $\left.>7 \mathrm{~m} \mathrm{~s}^{-1}\right)$ at each Bartlett Cove, the South Beardslee Islands and the North Beardslee Islands upon log-transformed daily Cancer magister megalopae abundance

\begin{tabular}{|c|c|c|c|c|}
\hline Source of variation & $\mathrm{df}$ & MS & $F$ & $\mathrm{p}$ \\
\hline \multicolumn{5}{|l|}{ Bartlett Cove } \\
\hline Lunar phase & 4 & 5.33 & 11.89 & $<0.0001$ \\
\hline Tidal amplitude & 4 & 2.87 & 6.41 & $<0.0001$ \\
\hline Wind speed & 2 & 1.15 & 2.57 & 0.0798 \\
\hline Lunar*Tidal & 4 & 2.07 & 4.62 & 0.0015 \\
\hline Lunar*Wind & 5 & 0.74 & 1.65 & 0.1515 \\
\hline Tidal ${ }^{*}$ Wind & 4 & 0.31 & 0.69 & 0.6013 \\
\hline Lunar*Tidal*Wind & 0 & 0 & & \\
\hline Error & 146 & 0.45 & & \\
\hline \multicolumn{5}{|c|}{ South Beardslee Islands } \\
\hline Lunar phase & 4 & 3.63 & 7.61 & $<0.0001$ \\
\hline Tidal amplitude & 4 & 3.08 & 6.46 & $<0.0001$ \\
\hline Wind speed & 2 & 3.03 & 6.36 & 0.0023 \\
\hline Lunar*Tidal & 4 & 2.23 & 4.68 & 0.0015 \\
\hline Lunar*Wind & 5 & 1.6 & 3.37 & 0.0068 \\
\hline Tidal ${ }^{*}$ Wind & 4 & 0.52 & 1.1 & 0.3614 \\
\hline Lunar*Tidal*Wind & 0 & 0 & & \\
\hline Error & 130 & 0.48 & & \\
\hline \multicolumn{5}{|c|}{ North Beardslee Islands } \\
\hline Lunar phase & 4 & 0.84 & 2.12 & 0.0818 \\
\hline Tidal amplitude & 4 & 0.1 & 0.26 & 0.9059 \\
\hline Wind speed & 2 & 0.06 & 0.16 & 0.8506 \\
\hline Lunar*Tidal & 4 & 1.01 & 2.55 & 0.0584 \\
\hline Lunar*Wind & 5 & 0.24 & 0.6 & 0.6625 \\
\hline Tidal $^{*}$ Wind & 4 & 0.4 & 1 & 0.3933 \\
\hline Lunar*Tidal*Wind & 0 & 0 & & \\
\hline Error & 132 & 0.4 & & \\
\hline
\end{tabular}



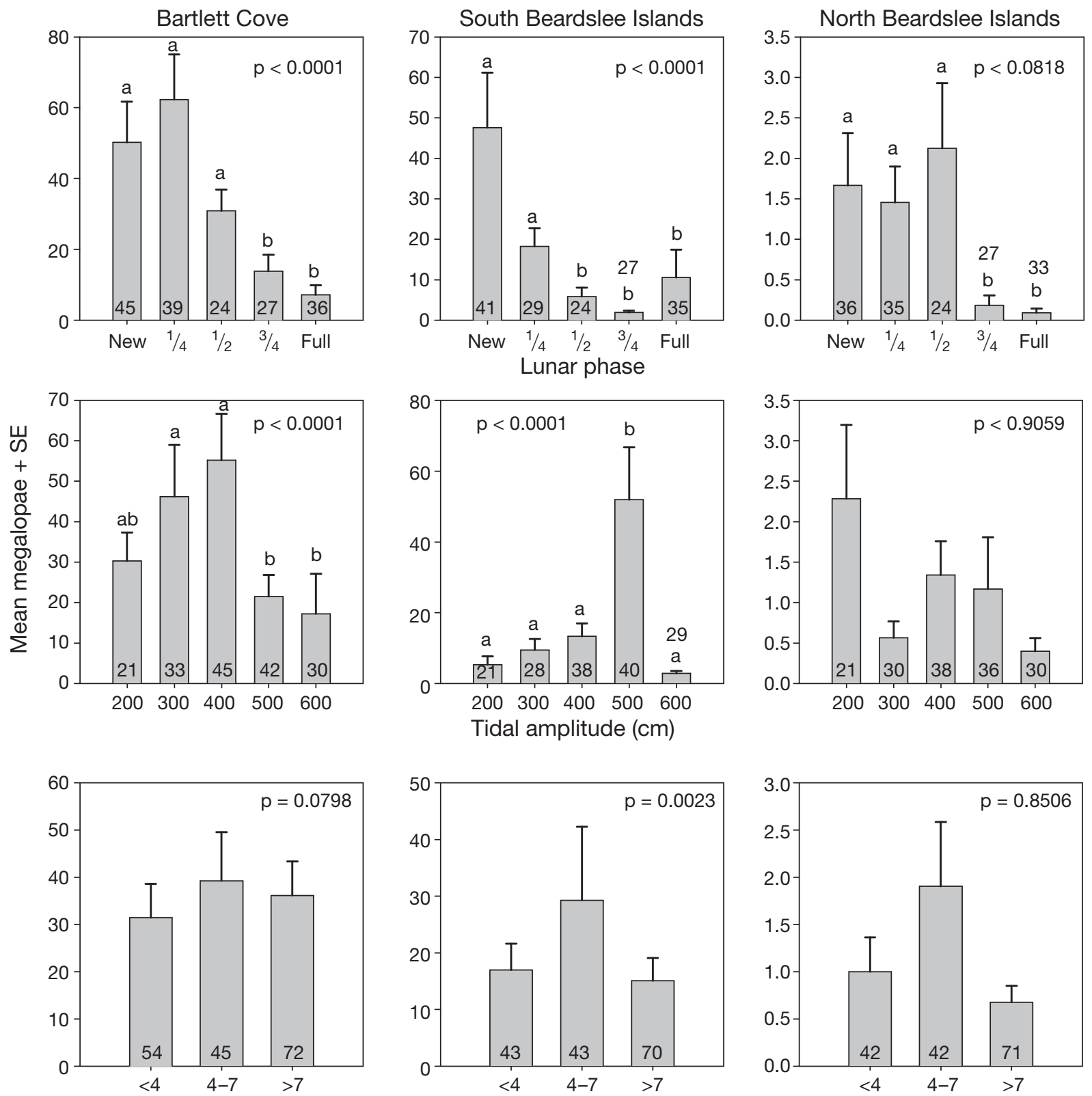

Maximum sustained wind speed $\left(\mathrm{m} \mathrm{s}^{-1}\right)$

Fig. 6. Cancer magister. Temporal variation in mean daily megalopae abundance per light trap for samples collected within $1 \mathrm{~m}$ of the surface at Bartlett Cove, the South Beardslee Islands and the North Beardslee Islands. Explanatory effects include lunar cycle (new, 1/4, 1/2,3/4 and full), tidal amplitude (200 to 299, 300 to 399, 400 to 499, 500 to 599 and 600 to 699 cm) and maximum sustained daily wind speed $\left(<4,4\right.$ to 7 and $\left.>7 \mathrm{~m} \mathrm{~s}^{-1}\right)$. Letters indicate significant differences among levels at $\mathrm{p}=0.05$. Note differences in $y$-axis scale among sites. Numbers in bars: number of samples

lated with maximum sustained wind speed. In SB correlations between megalopae abundance and lunar and tidal signals were not significant but did show the relationship between high megalopae abundances during new moon phases. Megalopae abundance was positively correlated with wind speed at lags of +2 to $3 \mathrm{~d}$ before winds ( $\mathrm{n}=43, \mathrm{p}=0.019$ to 0.031 ) and negatively correlated with wind speed at lags of $3 \mathrm{~d}$ after winds $(p=0.026)$. In NB, megalopae abundance was inversely correlated with tidal amplitude at 0 to $-1 \mathrm{~d}$ lags before tides ( $\mathrm{n}=43, \mathrm{p}=0.037$ to 0.040 ) and was positively correlated with lunar cycle at lags of 0 to $-3 \mathrm{~d}$ before the new moon, although more weakly than in BC ( $p=0.027$ to 0.046 ; Fig. 8). Mean daily tidal amplitude from 17 September to 31 October was $447.9 \pm 18 \mathrm{~cm}( \pm \mathrm{SE})$ and ranged from 223 to $646 \mathrm{~cm}$ 

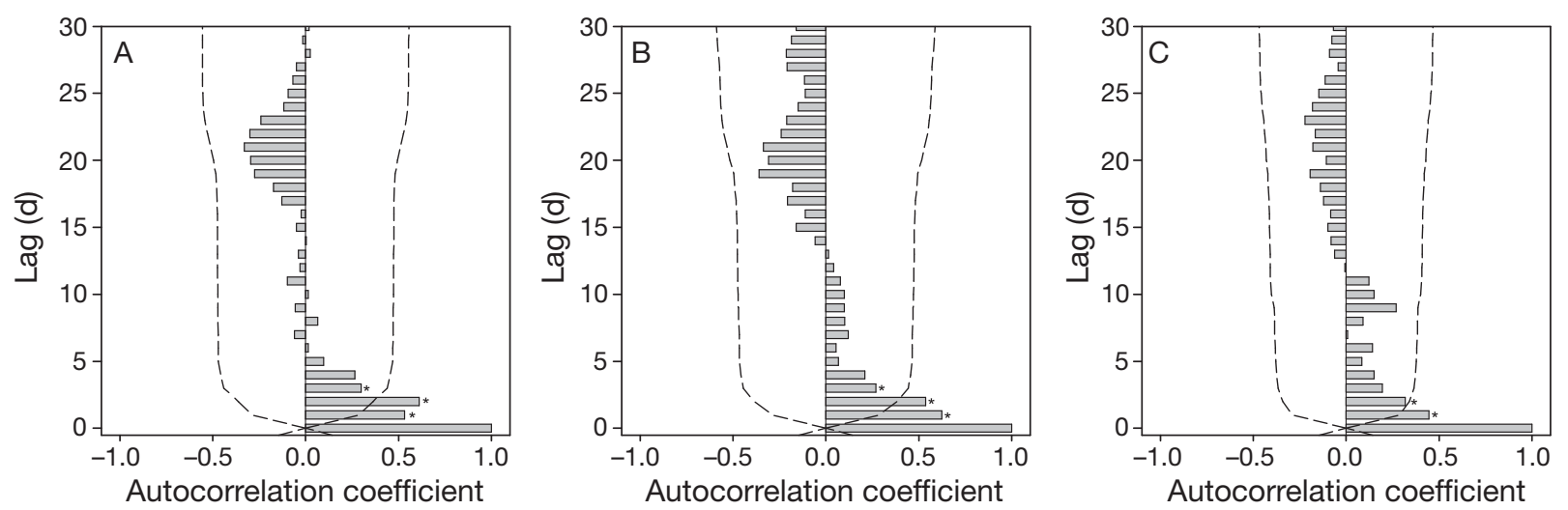

Fig. 7. Autocorrelations for residuals of megalopae supply at lags of up to $30 \mathrm{~d}$ for (A) Bartlett Cove, (B) the South Beardslee Islands and (C) the North Beardslee Islands. (---) 2 SE. * Significant autocorrelations at $\mathrm{p}=0.05$
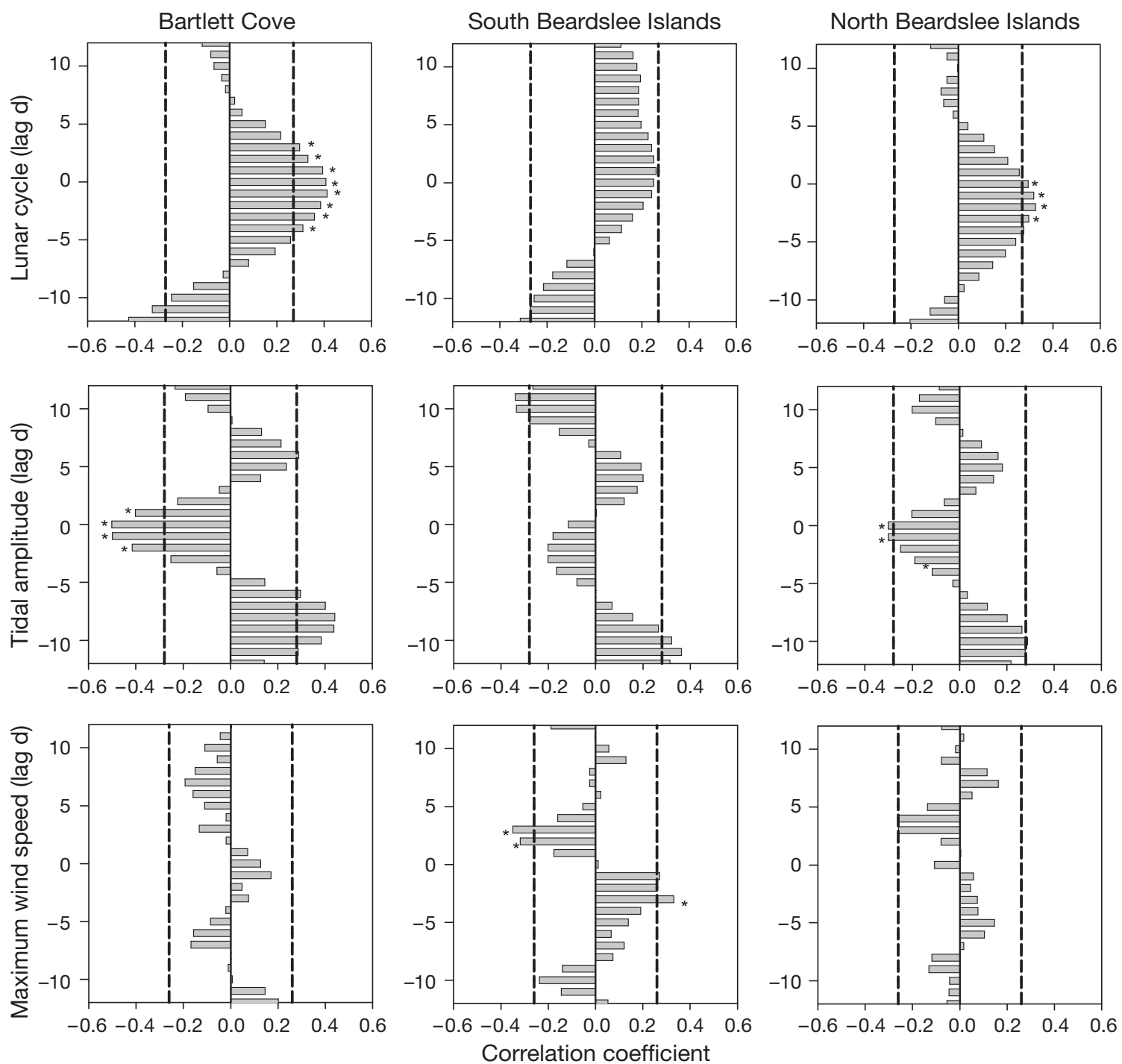

Fig. 8. Cross-correlations between residuals for Cancer magister megalopae abundance and maximum wind speed, tidal amplitude and lunar cycle for lags of $\pm 12 \mathrm{~d}$. Correlation coefficients shown for Bartlett Cove, the South Beardslee Islands and the North Beardslee Islands with negative lags representing events occurring prior to influx of megalopae. (----) 2 SE. ${ }^{*}$ Significant correlations at $\mathrm{p}=0.05$ 
( $\mathrm{n}=45)$. Maximum daily wind speeds ranged from 3.6 to $17.0 \mathrm{~m} \mathrm{~s}^{-1}$ with a mean daily wind speed of $6.8 \pm$ $0.4 \mathrm{~m} \mathrm{~s}^{-1}( \pm \mathrm{SE})$.

\section{DISCUSSION}

Surface traps captured 96.5 to $99.4 \%$ of the total megalopae at each site, supporting the idea that Dungeness crab larvae are transported into Glacier Bay as megalopae, after being exported from the Bay during early zoeal stages (Fisher 2005). This pattern of larval export and reinvasion has been repeatedly documented for Dungeness crab larvae along the outer coast of the continental USA but has not been previously observed in Alaska. Megalopae in nearshore waters off Vancouver Island, British Columbia, aggregate in surface waters at night and are found progressively closer to shore in later stages of intermolt (Jamieson \& Phillips 1988). Megalopae in nearshore areas make diurnal vertical migrations in which they are aggregated near the surface only during the night, sometimes showing peaks near dusk and dawn (Jamieson \& Phillips 1988, Jamieson et al. 1989, Hobbs \& Botsford 1992, Wing et al. 1998).

Light traps are a visual stimulus and are not a good estimate of megalopae abundance during the day. Therefore, it is unknown whether megalopae in Glacier Bay maintain their position in surface waters during the night and day or if they descend during daytime hours. During the day, megalopae off Vancouver Island were found in deeper waters or were diffuse through the top $15 \mathrm{~m}$ of the water column (Jamieson et al. 1989), whereas megalopae in offshore areas remain in surface waters during the day and night (Reilly 1983). If megalopae in Glacier Bay descend during the day, as is common in other nearshore areas, abundance in bottom traps may have been low because megalopae were aggregated at a different depth or were diffuse through the water column. Alternatively, light traps could experience a lower catch in areas with a higher sediment load in the water where light may be attenuated. If water clarity decreases near the bottom, light traps could underestimate the abundance of larvae present at that depth. However, Fisher (2005) observed a similar depth distribution in lower Glacier Bay at night using plankton tows, which are not affected by water clarity, with many megalopae present at the surface and few near the bottom. Megalopae may have been present closer than $1 \mathrm{~m}$ to the bottom, below the position of our traps. Depth-stratified plankton tows in $\mathrm{BC}$ during the day rarely caught megalopae at any depth; however, the tows generally remained several meters above the bottom (Fisher 2005). Megalopae were once caught in a daytime plankton tow that hit the ocean floor and brought up substrate (J. Fisher pers. comm.). Similarities in spatial variation in 2004 and 2005 suggest that decreased megalopae supply with increasing distance from the mouth of Glacier Bay may be consistent from year to year for these sites. Upon entering Glacier Bay, megalopae may encounter appropriate habitat in BC and SB and settle to the benthos, reducing the number of megalopae available for further up-Bay transport. An alternate hypothesis is that megalopae are adapted to settle near the mouths of estuaries as a way to avoid osmotic stress as juveniles. First instar juvenile Dungeness crabs are more sensitive to reduced salinity environments than other life stages and will hyperosmoregulate in seawater of less than 900 mOsm kg-1 (Brown \& Terwilliger 1992). Glacier Bay is characterized by a sharp change in salinity at ca. $40 \mathrm{~km}$ from the Bay's mouth where the well-mixed waters of the shallow (25 m) lower Bay shelf transition to the deep-stratified waters of the middle Bay (Hooge \& Hooge 2002). The upper reaches of Glacier Bay are characterized by a distinct freshwater layer at the surface due to runoff, stream output and glacial melt (Hooge \& Hooge 2002). Cancer magister megalopae may therefore settle close to the mouth of Glacier Bay as a reflection of osmotic preference.

Either of these mechanisms could result in high settlement in the lower Bay or a gradient of decreasing settler abundance with increasing distance from the mouth of the Bay. Adult Dungeness crabs are disproportionately distributed in Glacier Bay with $88 \%$ of all adults found within $40 \mathrm{~km}$ of the Bay's mouth (Taggart et al. 2003). Salinity, temperature and turbidity were measured from the lower to the upper Bay to characterize changes in habitat, but no abiotic factor was determined that might be limiting to adult populations where adult crabs are rare. Physical conditions may be limiting to some earlier stage or megalopal supply may be a limiting factor in that area. The crabs in the upper Bay were predominantly large males, suggesting that they were either able to tolerate extreme salinity or temperature events that others were not or that recruitment to the upper Bay is low or periodic and these individuals simply walked up from the lower Bay. Spatial variations in late-stage larvae of the snow crab Chionoecetes opilio and pandalid shrimp Pandalus montagui were related to variations in adult abundance at 2 sites in a western Canadian fjord separated by only a few kilometers (Quijon \& Snelgrove 2005). Similarly, megalopae supply may affect the spatial distribution of adult Dungeness crabs in Glacier Bay.

Timing of megalopae supply in the lower portion of Glacier Bay varied among sites and may result from differences in transport processes over just a few kilometers. These differences were surprising because of 
the relatively short distance between sites and similar position of all sites on the east side of Glacier Bay. Long-term studies of Dungeness crab recruitment in northern California and Oregon suggest that variation in larval abundance at relatively small scales (1 to $10 \mathrm{~km}$ ) is most greatly influenced by oceanographic processes that affect larval transport (Botsford et al. 1989, 1998, Botsford 2001, Shanks \& Roegner 2007). Differences in local hydrodynamics may affect the observed variations in megalopae supply to BC, SB and NB.

Larval transport processes are often difficult to determine, because larval behavior and hydrodynamic processes can interact in complex ways that prohibit generalizations (Shanks 1995, Queiroga \& Blanton 2004). The main mechanism transporting megalopae into Glacier Bay is likely an interaction between lunar and tidal effects. Megalopae supply to SB was highest on the new moon, whereas supply to BC and NB was generally stretched over a wider array of lunar phases, from new to $1 / 2$ moons. Peaks in Cancer magister megalopae abundance have been related to both neap tides near $1 / 2$ or $1 / 4$ moons (Johnson \& Shanks 2002, Miller \& Shanks 2004) and to spring tides near new and full moons (Miller \& Shanks 2004), but both of these effects have not previously been observed for C. magister megalopae within such a small area.

Megalopae behavior may facilitate transport into Glacier Bay during dark phases of the moon as a predator avoidance tactic by making vertical migrations to avoid surface waters during the week of the full moon. Cancer magister megalopae are excellent swimmers with swimming speeds of $8.5 \mathrm{~cm} \mathrm{~s}^{-1}$ in still water and up to $44.8 \mathrm{~cm} \mathrm{~s}^{-1}$ against current speeds of $40 \mathrm{~cm} \mathrm{~s}^{-1}$ (Fernandez et al. 1994). During mid-amplitude tides, megalopae are most likely to be pushed into BC with surface currents, whereas megalopae are deposited in SB during higher amplitude tides (Fig. 9). The lack of a clear $14 \mathrm{~d}$ periodicity in the autocorrelation analyses supports the idea that tidal currents alone do not control the influx of megalopae into Glacier Bay, but that tides may be an important mechanism for transport during appropriate lunar phases.

Our understanding of Glacier Bay hydrodynamics has been greatly improved by a recent 2-dimensional oceanographic modeling project which extrapolates data presented in Etherington et al. (2004) to describe surface tidal currents in Glacier Bay and the adjacent Icy Strait (Hill 2007). The final products of the present study include vector fields describing the direction and speed of tidally driven surface currents as well as trajectories for particle movement (i.e. megalopae) in and out of the Bay with tides. Simulations followed the trajectories of 6 particles positioned across the Bay mouth over a $2 \mathrm{~d}$ period beginning on each spring flood, spring ebb, neap flood and neap ebb tidal conditions (4 trials each). The model may lend important insight when considering how transport processes might result in the small-scale differences in megalopae supply observed in the present study.

Near the entrance to $\mathrm{BC}$, tidal currents are among the weakest in Glacier Bay, whereas tidal currents in Sitakaday Narrows (leading into SB) are among the strongest (Hill 2007). In simulations of neap flood tides, particles from across the mouth of Glacier Bay traveled just into the lower portion of the Bay without transport into Sitakaday Narrows or BC (Hill 2007). Megalopae transported into the lower Bay on flooding neap tides may be able to maintain their position in surface waters and utilize subsequent tides or winds for transport into BC. On flooding spring tides, and during no other conditions, tidal currents carried 5 of 6 particles from the mouth of Glacier Bay into and through Sitaka-

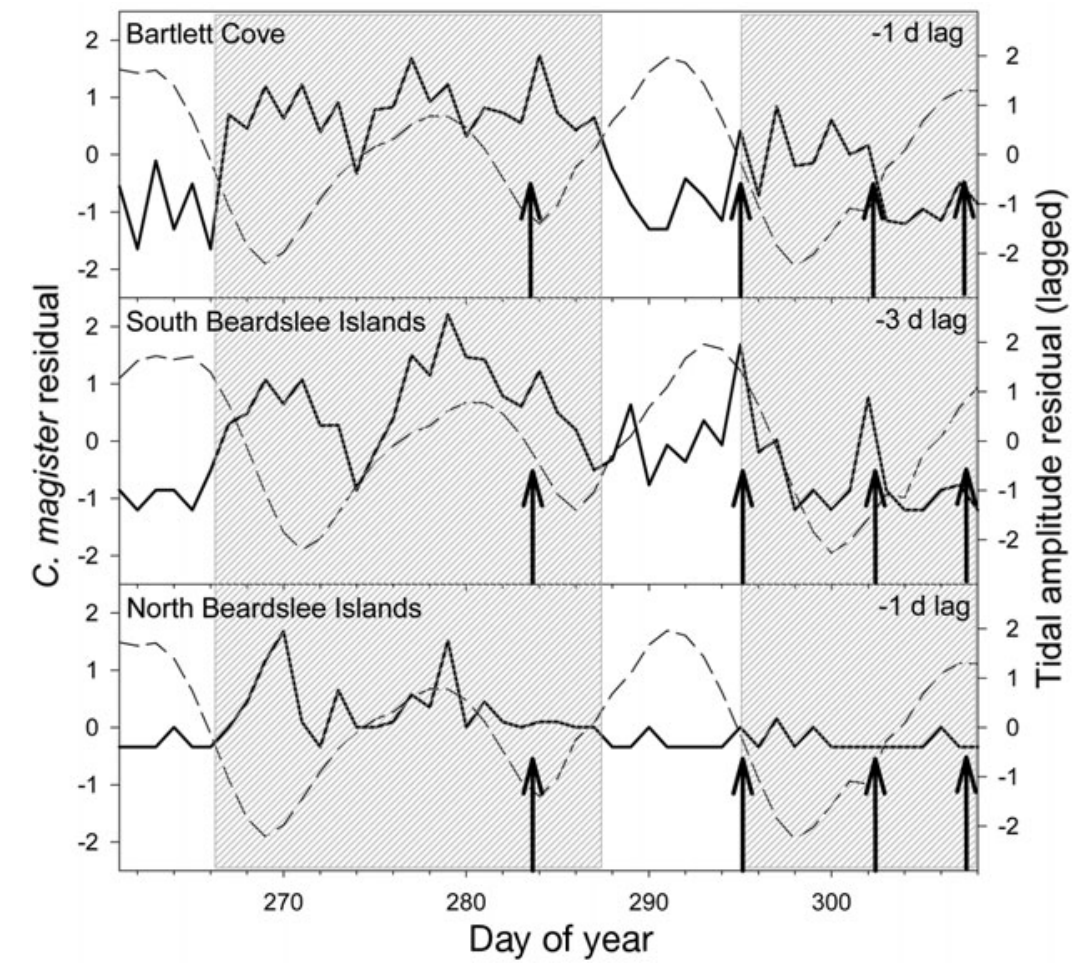

Fig. 9. Cancer magister. Time series of megalopae residuals (-) shown with wind events greater than $10 \mathrm{~m} \mathrm{~s}^{-1}$ (arrows), tidal amplitude $(---)$ and lunar cycle (full moon periods unshaded). Tidal amplitude shown at lags significantly cross-correlated with megalopae supply: Bartlett Cove $=-1 \mathrm{~d}$; South Beardslee Islands $=-3 \mathrm{~d}$ and North Beardslee Islands $=-1 \mathrm{~d}$. Megalopae residuals are equal to $\log _{10}($ abundance +0.1 ) minus the mean megalopae abundance at that site during the study period 
day Narrows and 1 to the mouth of BC (Hill 2007). During maximum ebb or flood on high amplitude tides, such as when we see high numbers of megalopae in $\mathrm{SB}$, surface waters in Sitakaday Narrows have been described as 'a highly turbulent fast-flowing river, with standing waves, whirlpools and roils' (Hooge \& Hooge 2002). Average tidal currents in Sitakaday Narrows measure 2.6 and $2.7 \mathrm{~m} \mathrm{~s}^{-1}$ during ebb and flood tides, respectively, with maximum current speeds of $4.5 \mathrm{~m} \mathrm{~s}^{-1}$ (Hooge \& Hooge 2002). In this extreme environment, megalopae may simply be swept into SB in high numbers on flooding spring tides.

Wind effects at low $\left(<4 \mathrm{~m} \mathrm{~s}^{-1}\right)$, moderate $\left(4\right.$ to $\left.7 \mathrm{~m} \mathrm{~s}^{-1}\right)$ and high $\left(>7 \mathrm{~m} \mathrm{~s}^{-1}\right)$ levels were difficult to interpret as there was no direct relationship with megalopae abundance at any site, and only one significant interaction occurred, between moderate winds and lunar cycle, in SB. Wind was also cross-correlated with megalopae abundance at that site, but the semi-regular 12 to $14 \mathrm{~d}$ periodicity in high wind events may have confounded the effects of wind and tides. Correlations occurred both 2 to $3 \mathrm{~d}$ before and after wind events, which may be nonsensical (Fig. 9). Larval settlement for Dungeness crabs in this region occurs over a relatively short period of time, therefore the length of our time series in both short and correlations may be affected by chance events.

Our analysis detected no effect of high winds (defined at $>7 \mathrm{~m} \mathrm{~s}^{-1}$ ) on megalopae abundance at any site; however, storm events (i.e. maximum sustained wind speeds $>10 \mathrm{~m} \mathrm{~s}^{-1}$ ) may have had a greater effect on megalopae supply than high winds, especially when lunar and tidal conditions are appropriate for transport. Days with storm events seem to be associated with pulses in megalopae abundance (Fig. 9), although these events were too rare to analyze as a separate effect. During a major storm on the $1 / 2$ moon of 10 October (maximum sustained wind $12.9 \mathrm{~m} \mathrm{~s}^{-1}$ ), night samples were collected from surface light traps at the dock in BC (authors' unpubl. data). At that time, swarms of megalopae were visible in surface waters and covered the outside of the light traps. One megalopae pulse associated with high winds in SB actually occurred on a $3 / 4$ moon, suggesting that wind-driven mixing may be strong enough to inhibit vertical migrations (Fig. 9). Storms have been shown to affect dispersal and spatial distribution of brachyuran crab megalopae (McConnaughey et al. 1992, Etherington \& Eggleston 2000).

The present study presents evidence that Cancer magister megalopae are transported into Glacier Bay by behaviors related to lunar phase and physical forcing mechanisms including tides and wind; however, the results are difficult to extrapolate throughout the region. The oceanography of southeast Alaska is com- plex, and substantial variation in megalopae supply, as well as in transport processes, exists over distances of less than $10 \mathrm{~km}$. Glacier Bay is also linked closely with the outside waters of the GOA, and this system of export and reinvasion of Glacier Bay by Dungeness crab larvae may not hold throughout the inside waters of southeast Alaska.

Acknowledgements. We thank Alaska Sea Grant for funding. We are grateful to Dr. J. Taggart, Dr. T. Shirley, and 3 anonymous reviewers for advice and edits. Project logistics were assisted by employees of the US Geological Survey and the National Park Service. We are grateful for help from many volunteers and technicians.

\section{LITERATURE CITED}

Bence JR (1995) Analysis of short time series: correcting for autocorrelation. Ecology 76:628-639

Botsford LW (2001) Physical influences on recruitment to California Current invertebrate populations on multiple scales. ICES J Mar Sci 58:1081-1091

Botsford LW, Armstrong DA, Shenker JM (1989) Oceanographic influences on the dynamics of commercially fished populations. In: Landry M, Hickey B (eds) Coastal oceanography of Washington and Oregon. Elsevier, Amsterdam, p 511-565

Botsford LW, Moloney CL, Largier JL, Hastings A (1998) Metapopulation dynamics of meroplanktonic invertebrates: the Dungeness crab Cancer magister as an example. In: Jamieson GS, Campbell A (eds) Proc North Pac Symp Invertebr Stock Assess Manage. Can Spec Publ Fish Aquat Sci 125:295-306

Brown AC, Terwilliger NB (1992) Developmental changes in ionic and osmotic regulation in the Dungeness crab, Cancer magister. Biol Bull (Woods Hole) 182:270-277

Carrasco KR, Armstrong DA, Gunderson DR, Rogers C (1985) Abundance and growth of $C$. magister young-of-the-year in the nearshore environment. Proc Symp Dungeness Crab Biol Manage. Sea Grant Report 85:273-286

Department of the Interior (1998) Glacier Bay National Park, $\mathrm{AK}$; Commercial fishing regulations final rule. Fed Regist 63(238):56455-56464

- Eggleston DB, Armstrong DA (1995) Pre- and post-settlement determinants of estuarine Dungeness crab recruitment. Ecol Monogr 65:193-216

Emery WJ, Thomson RE (1997) Data analysis methods in physical oceanography. Pergamon Press, Oxford

Etherington LL, Eggleston DB (2000) Large-scale blue crab recruitment: linking postlarval transport, post-settlement planktonic dispersal, and multiple nursery habitats. Mar Ecol Prog Ser 204:179-198

Etherington LL, Hooge PN, Hooge ER (2004) Factors affecting seasonal and regional patterns of surface water oceanographic properties within a fjord estuarine system: Glacier Bay, AK. Glacier Bay Field Station, US Geological Survey, Alaska Science Center, Gustavus, AK

Etherington LL, Hooge PN, Hooge ER, Hill DF (2007) Oceanography of Glacier Bay, Alaska: implications for biological patterns in a glacial fjord estuary. Estuar Coast 30: 927-944

> Fernandez M, Iribarne OO, Armstrong DA (1994) Swimming behavior of Dungeness crab, Cancer magister Dana, mega- 
lopae in still and moving water. Estuaries 17:271-275

Fisher J (2005) Larval dynamics of brachyuran crabs in a high latitude fjord, Southeast Alaska. Moss Landing Marine Laboratories, Moss Landing, CA

Fisher J (2006) Seasonal timing and duration of brachyuran larvae in a high-latitude fjord. Mar Ecol Prog Ser 323: 213-222

Herter HL (2007) Transport of Dungeness crab (Cancer magister) megalopae into Glacier Bay, Alaska. MS thesis, University of Alaska Fairbanks School of Fisheries and Ocean Sciences, Juneau, AK

Hill DF (2007) Tidal modeling of Glacier Bay, Alaskamethodology, results and applications. The Pennsylvania State University Department of Civil and Environmental Engineering, University Park, PA

$>$ Hobbs RC, Botsford LW (1992) Diel vertical migration and timing of metamorphosis of larvae of the Dungeness crab C. magister. Mar Biol 112:417-428

Hooge PN, Hooge ER (2002) Fjord oceanographic processes in Glacier Bay, Alaska. Glacier Bay Field Station, US Geological Survey, Alaska Science Center, Gustavus, AK

> Huyer A (1983) Coastal upwelling in the California current system. Prog Oceanogr 12:259-284

Jamieson GS, Armstrong DA (1991) Spatial and temporal recruitment patterns of Dungeness crab in the northeast Pacific. Mem Qld Mus 31:365-381

Jamieson GS, Phillips AC (1988) Occurrence of Cancer crab (C. magister and C. oregonensis) megalopae off the west coast of Vancouver Island, British Columbia. Fish Bull (Wash DC) 86:525-542

Jamieson GS, Phillips A (1993) Megalopal spatial distribution and stock separation in Dungeness crab (C. magister). Can J Fish Aquat Sci 50:416-429

Jamieson GS, Phillips AC, Huggett WS (1989) Effects of ocean variability on the abundance of Dungeness crab (Cancer magister) megalopae. In: Bearnish RJ, McFarlane GA (eds) Effects of ocean variability on recruitment and an evaluation of parameters used in stock assessment models. Can Spec Publ Fish Aquat Sci 108:305-325

Johnson J, Shanks AL (2002) Time series of the abundance of the post-larvae of the crabs C. magister and Cancer spp. on the southern Oregon coast and their cross-shelf transport. Estuaries 25:1138-1142

Jones MB, Epifanio CE (2005) Patches of crab megalopae in the mouth of Delaware Bay - an analysis of spatial scales. J Shellfish Res 24:261-267

Lough RG (1974) Dynamics of crab larvae (Anomura, Brachyura) off the Central Oregon Coast. PhD dissertation, Oregon State University, Corvallis, OR

Lough RG (1976) Larval dynamics of the Dungeness crab, Cancer magister, off the central Oregon coast, 1970-71. Fish Bull (Wash DC) 74:353-376

Love MS, Westphal MV (1981) A correlation between annual catches of Dungeness crab, Cancer magister, along the west coast of North America and mean annual sunspot number. Fish Bull (Wash DC) 79:794-796

McConaugha JR (1988) Export and reinvasion of larvae as regulators of estuarine decapod populations. Am Fish Soc Symp 3:90-103

McConnaughey RA, Armstrong DA, Hickey BM, Gunderson DR (1992) Juvenile Dungeness crab (C. magister) recruitment variability and oceanic transport during the pelagic larval phase. Can J Fish Aquat Sci 49:2028-2044

> Miller JA, Shanks AL (2004) Ocean-estuary coupling in the Oregon upwelling region: abundance and transport of juvenile fish and crab megalopae. Mar Ecol Prog Ser 271: 267-279
Natunewicz CC, Epifanio CE (2001) Spatial and temporal scales of patches of crab larvae in coastal waters. Mar Ecol Prog Ser 212:217-222

O'Clair CE, Freese L, Stone R, Shirley TC, Leder E, Taggart SJ, Kruse G (1995) Nearshore distribution and abundance of Dungeness crabs in Glacier Bay National Park Alaska. In: Engstrom DR (ed) Proc 3rd Glacier Bay Sci Symp 1993. US National Parks Service, Anchorage, AK, p 196-202

O'Clair CE, Shirley TC, Taggart SJ (1996) Dispersion of adult Cancer magister at Glacier Bay, Alaska: variation with spatial scale, sex, and reproductive status. In: Keller S, Kaynor C (eds) Proc Symp, High Latitude Crabs: Biology, Management and Economics. Alaska Sea Grant College Program, Fairbanks, AK, p 209-227

> Porter SS, Eckert GL, Byron CJ, Fisher JL (2008) Comparison of light traps and plankton tows for sampling brachyuran crab larvae in an Alaskan fjord. J Crustac Biol 28:175-179

Queiroga H, Blanton J (2004) Interactions between behaviour and physical forcing in the control of horizontal transport of decapod crustacean larvae. Adv Mar Biol 47:107-214

- Quijon PA, Snelgrove PVR (2005) Spatial linkages between decapod planktonic and benthic adult stages in a Newfoundland fjordic system. J Mar Res 63:841-862

Reilly PN (1983) Dynamics of Dungeness crab, Cancer magister, larvae off central and northern California. In: Wild PW, Tasto RN (eds) Life history, environment, and mariculture studies of the Dungeness crab, Cancer magister, with emphasis on the central California fishery resource. Fish Bulletin 172, California Department of Fish and Game, Menlo Park, CA, p 57-84

Reyns N, Sponaugle S (1999) Patterns and processes of brachyuran crab settlement to Caribbean coral reefs. Mar Ecol Prog Ser 185:155-170

Roegner GC, Armstrong DA, Hickey BM, Shanks AL (2003) Ocean distribution of Dungeness crab postlarvae and recruitment patterns to estuaries in southern Washington state. Estuaries 26:1058-1070

Royer TC (1998) Coastal processes in the northern North Pacific. In: Robinson AR, Brink KH (eds) The sea. John Wiley \& Sons, New York, p 395-414

Shanks AL (1995) Mechanisms of cross-shelf dispersal of larval invertebrates and fish. In: McEdward L (ed) Ecology of marine invertebrate larvae. CRC Press, Boca Raton, FL, p 323-368

Shanks AL (ed) (2001) An identification guide to the larval marine invertebrates of the Pacific Northwest. Oregon State University Press, Corvallis, OR

> Shanks AL (2006) Mechanisms of cross-shelf transport of crab megalopae inferred from a time series of daily abundance. Mar Biol 148:1383-1398

Shanks AL, Roegner GC (2007) Recruitment limitation in Dungeness crab populations is driven by variation in atmospheric forcing. Ecology 88:1726-1737

Sverdrup HU, Johnson MW, Fleming RH (1942) The oceans: their physics, chemistry, and general biology. PrenticeHall, Englewood Cliffs, NJ

Taggart SJ, Hooge PN, Mondragon J, Hooge ER, Andrews AG (2003) Living on the edge: distribution of Dungeness crab Cancer magister in a recently deglaciated fjord. Mar Ecol Prog Ser 246:241-252

Taggart SJ, O'Clair CE, Shirley TC, Mondragon J (2004a) Estimating Dungeness crab (Cancer magister) abundance: crab pots and dive transects compared. Fish Bull (Wash DC) 102:488-497

Taggart SJ, Shirley TC, O'Clair CE, Mondragon J (2004b) Dramatic increase in the relative abundance of large male Dungeness crabs Cancer magister following closure of 
commercial fishing in Glacier Bay, Alaska. Am Fish Soc Symp 42:243-253

US Department of Commerce (2006) Wind data for station 703670. National Climatic Data Center, Gustavus, AK. Available at: http://cdo.ncdc.noaa.gov/pls/plclimprod/ cdomain.abbrev2id (accessed October 10, 2006)

US Naval Observatory (USNO) (2005) Lunar calendar data for 2004 and 2005. Astronomical Applications Department, USNO, Washington, DC. Available at: http://aa.usno. navy.mil/data/docs/MoonPhase.php (accessed 20 November 2005)

University of South Carolina (USC) (2006) XTide tide predictor for Bartlett Cove, Glacier Bay. Department of Biological Sciences USC, Columbia, SC. Available at: http://

Editorial responsibility: Steven Morgan,

Bodega Bay, California, USA tbone.biol.sc.edu/tide/sitesel.html (accessed January 2006)

Weingartner TJ, Danielson SL, Royer TC (2005) Freshwater variability and predictability in the Alaska Coastal Current. Deep-Sea Res II 52:169-192

Wing SR, Largier JL, Botsford LW (1998) Coastal retention and longshore displacement of meroplankton near capes in eastern boundary currents: examples from the California Current. S Afr J Mar Sci 19:119-127

Woodby D, Carlile D, Siddeek S, Funk F, Clark JH, Hulbert L (2005) Commercial fisheries of Alaska. Spec Publ 05-09. Alaska Department of Fish and Game, Division of Commercial Fisheries, Juneau, AK. Available at: www.sf.adfg. state.ak.us/FedAidPDFs/sp05-09.pdf

Submitted: December 20, 2007; Accepted: July 25, 2008

Proofs received from author(s): November 21, 2008 